\title{
防菌防徵分野における薬剤利用
}

\author{
西 村民男
}

北里大学衛生学部化学科

(昭和 55 年 3 月 5 日受理)

\section{Industrial Utilization of Antibacterial and Antifungal Compounds}

\author{
Tamio Nishimura \\ Department of Chemistry, School of Hygienic Sciences, Kitasato University \\ Yokohama, Kanagawa 228, Japan
}

\section{は じめに}

細菌類やカビ類の増殖によって惹き起こされる災害は 微生物災害とよばれ，非常に広い分野にわたって種々の 問題を提起している。これらの災害の防止に防菌防徽剂 が使用されているが，その数は非常に多く，応用される 分野によって使用される薬剤の種類も違っている．防菌 防徵剂は，応用分野から見ると，工業用，農業用，飼料 用, 食品用, 医薬用, 化粧品用および環境用に大別され る.ここでは，主として工業用防菌防徽剤をとりあげ， どのような薬剤が使用されているか紹介してみたいと思 う。構造式を眺めてみると, 農薬開発の副産物として生 まれてきたと思われるものもあり, 農薬の開発研究に伴 って合成される膨大な化合物のなかには工業用防菌防徽 凨として優れた性質をもつものも存在するかもしれな い. 工業用防菌防徽版に要求される諸性状は分野によっ て異なり，各分野において満足すべき諸性状を完備した 防菌防徵剤はほとえぞないのが現状である．農薬研究者 がこのような視点から農薬開発研究を眺めることによ り，新しい工業用防菌防徽戍が出現することを期待した いものである：また，工業用に用いられている薬戍の構 造から，新しい農薬を開発するヒントが得られれば幸い である。

\section{工業用防菌防徽剤の備えるべき条件}

一般的条件としては，(1) 抗菌抗力ビ力の強いこと, （2）人体および環境等に対して安全性の高いこと，（3） 必要とされる期間残効性のあること，(4) 価格が妥当で
あること，(5) 色や臭いのないこと，であるが，使用領 域により, 特殊な条件が必要とされるので分野別に簡単 に説明する。

1) 木 材 用

（1）木材腐朽菌, 変色菌 およびカビに有効なこと, （2）処理木材の耐候性がよいこと，(3) 木材への浸透性 がよいこと，(4) 吸湿性，塗装性，接着性などに支障の ないこと.

2）スライム用

（1）製紙の操業性をさまたげぬこと，(2) 紙質に影響 のないこと，(3) 用水の循環使用, 廃水の再利用に悪影 響のないこと。

3）瀻維材料用（主として衛生加工）

（1）繊維の物理的性質（強さ，柔らかさなど）に影響 しないこと，(2) 繊維に吸着性があり，洗濯後にも効果 を示すこと，(3) 皮膚刺激性のないとと。

4) 皮革 用

（1）染色に影響しないこと，（2）革の物理的性質に影 響しないこと。

5) 塗料用（エマルジョン塗料などの貯藏時の防菌剛 および塗膜の防徵剤の 2 種がある)

（1）塗料と相溶性のよいこと（白濁, 沈殿, 分離, 増 粘，ゲル化などを起こさないこと)，（2）塗装のさいの 熱，pH などに対し安定であること，(3) 塗膜表面に析 出したり，塗膜むらを生じないこと，(4) 金属を腐食し ないこと。

6）水系組成物（ゴム，ラテックス，切削油，金属工 作油, 繊維油, 糊, 接着剂, 合成樹脂エマルジョ 
ンなど）

（1）乳化安定性のよいこと，（2）材料の物性などに影 響のないこと。

7）プラスチック用

（1）相溶性であること，(2) 染色に影響しないこと， （3）材料の性能をそこなわないこと。

\section{微生物災害の具体例}

\section{1）金 属 類}

航空機の燃料タンクや熱交換器のアルミニウムは微生 物腐食を受けることが明らかにされている．水中や土堙 中に長期にわたって埋没して使われる鉄管などは，化学 的あるいは電気化学的腐食のほかに, 鉄バクテリア, 硫 黄バクテリア, 硫酸還元菌などによって腐食される. 火 力発電所の冷却水用銅製パイプの内面が，硫酸還元菌な ぞによってはげしい腐食を受けた例も知られている。

2) ガ

時計や計器に使うガラス板を紙で包んで倉庫に保管し ておくと，細菌やカビが繁殖してガラス板によごれが発 生し，作業能率が著しく低下した事例が報告されてい る.もちろん，その原因はガラスの表面を保護する目的 で使用していたティッシュペーパーと包装に用いたクラ フト紙の污染であった。

またフィリッピンの新しい工場で製造したメーターを 包装して出荷したところ, 数週間後にはガラスの内側に カビが発育し，1〜2 カ月後にはメーターの文字盤が見 えなくなった例も報告されている．新工場の周囲には広 大なサトウキビ畑があり，気候風土の関係でカビの発育 がさかんであり，工場内にもカビが侵入し作業室の污染 度が高まったことがその原因とされている.

光学機器のレンズやプリズムの表面にも, 湿度の低い 環境でのみよく生育する珍しい性質をもつカワキフオコ ウジカビが繁殖して材質を腐食することが知られてい る.

\section{3) 塗 料}

食品工場, 製薬工場, 化粧品の工場, 紡績工場, 製紙 工場, 印刷工場, 包装材料のメーカーなどでは, 原料倉 庫, 製品の加工室, 製品倉庫などの塗装したところにカ ビが発育し，それが製品の 2 次污染の大きな原因となっ ている. 合成樹脂系のペイントや一般の油性のエナメル などのように, 表面の硬度の小さいものはカビによる作 用を受けやすい．化学的に安定なエポキシ樹脂叙料やポ リウレタン樹脂塗料はカビの作用を受けないと信じられ てきたが, Fusarium 菌, Curvularia 菌, Ulocladium 菌, Trichoderma 菌などによって变質劣化することが,
井上真由美氏によって明らかにされている。

無公害の画期的塗装方式ということでさかんに用いら れている電着塗装では, 浴槽内の温度が $25 \sim 30^{\circ} \mathrm{C}$ であ るためスライム状の菌が繁殖しやすい好条件にあり，特 殊なフィルタやシャワのノズルがつまり作業上の障害に なっているとのことである.

水系塗料やエマルジョン塗料は貯蔵中に各種の微生物 が増殖して变質を起こしやすい. エマルジョン塗料中の 乳化剂, 可塑郕, 増粘棛, 界面活性剂, 保護コロイドな ぞは菌の栄養に好適な物質である.

4) 油郕

エマルジョンタイプの切削油には, 動植物油, エステ ル，リン化合物などが用いられている，このような成分 は細菌やカビの好適な栄養源である.ソリューションタ イプの油剤には，アミンやアミドなどの有機化合物に界 面活性剂が混合されており，これらも微生物が好む成分 である．これらの油鼡に多くの種類の微生物が繁殖する のは, これらの栄養源に加えて, 油剂に添加されている 水に原因がある. 微生物が増殖すると，切削油ではェマ ルジョンが破壊され，液が分離して黒色の浮遊物を生じ るようになる。浮遊物とスライムは, コック, 配管, フ ィルタをつまらせ，液の $\mathrm{pH}$ は急速に低下して，工具や 加工材料はさびやすくなる. 油剤のなかに増殖する微生 物は細菌, カビ, 酵母などで, きわめて生活力の強い土 袞菌が多い。

\section{5) プラスチック}

プラスチック材料はゴミとして捨てられた場合に，な かなか腐りにくいところから，微生物によって分解され ないと考えられているようである.しかし，電線の被覆 に用いられているポリ塩化ビニル樹脂では, 可塑郕や添 加戍が多量に用いられているため, 土壇菌によって被害 を受ける例がきわめて多い。これらが微生物によって利 用されると, 被覆のポリ塩化ビニルはもろくなり, やが てさけて中心の導体が露出する結果となる. カビの菌系 はプラスチックのなかへ中心に向かって食いこむ性質が あり, 電気絶縁性は急速に低下寸る。微生物の作用で変 質劣化しやすい材料は, ポリウレタン樹脂, シリコン樹 脂, ポリ塩化ビニル樹脂, エポキシ樹脂, ネオプレンで あることが井上真由美氏の長年にわたる研究で明らかに されている.電気機器や自動制御装置が海外に輸出され る場合，熱帯地区を通過するさい，船倉のなかでむれて プラスチック材料部分が微生物により被害を受ける例が 多く知られている.

そのほか, 微生物災害が問題となっている分野には, 木材, 接着剂とのり, 瀻維製品, 皮革製品, 包装材料, 
化粧品, 医薬品, 食品, 家庭用品, 文化財などいろいろ あるが，その具体例は省略する。

\section{防菌防徽剂の種類と応用分野}

市販されている多種類の防菌防徽剂をわかりやすく分 類することはむずかしいが，以下筆者の考えた分類に従 って代表的薬剤とその応用分野索説明する. 分類は化学 構造に立脚したものであり, 防菌防徽作用を発揮する主 作用団に注目している. しかし, 工業用防菌防徽剤に関 しては作用機作の研究が少なく, 注目している官能基が 本当に作用機作に関係しているかどうかはわかっていな い場合が多いので，主作用団はたんなる推測にすぎな い。また応用分野に関しても, 実際に使用されている薬 品の構造が公表されていない場合も多く, この分類に包 含されていないものもあることをご承知いただきたい。

1) 第 4 級アソモニウム塩

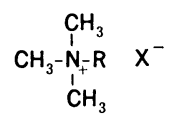

1

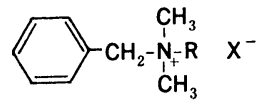

2<smiles>[Y]c1cccc[n+]1[R]</smiles>

現在殺菌剤あるいは防腐剂として広く利用されている ものは，アルキルトリメチルアンモニウム塩 (1)，アル キルジメチルベンジルアンモニウム塩 $(2)$, およびアル キルピリジニウム塩（3）の 3 種である.

アルキルトリメチルアンモニウムクロリドの殺菌力は E. coli に対してはアルキル基の炭素数が $\mathrm{C}_{18}$ のとき最
大であり，S. aureus に対しては $\mathrm{C}_{16}$ のときが最大とな っている. アルキルジメチルベンジルアンモニウムクロ リドでは $\mathrm{C}_{14}$ と $\mathrm{C}_{12}$ の場合が殺菌力が強い. アルキル ピリジウムハライドでは $\mathrm{C}_{16}$ が最大の殺菌力を示す． 2 に分類される塩化ベンザルコニウムはファンサイド 930, クォーターセプトなどの市販品があり, 塗料, ス ライムコントロール, 殺菌消毒に用いられ， 3 に属する ヘキサデシルピリジニウム塩は繊維に使用される. 構造 活性相関式をいくつか示す.

2 の $A$. niger に対する殺力ビ活性

$$
\begin{aligned}
& \log 1 / c=-0.223(\log p)^{2}+1.027 \log p \\
&+2.592( \pm 0.83) \\
& n=10, \quad r=0.720, \quad s=0.477, \quad \log p_{0}=2.3
\end{aligned}
$$

2 の A. niger に対する静カビ活性

$$
\begin{aligned}
& \log 1 / c=-0.237(\log p)^{2}+1.040 \log p \\
&+3.114( \pm 0.26) \\
& n=11, \quad r=0.947, \quad s=0.224, \quad \log p_{0}=2.2
\end{aligned}
$$

2) アミン塩

$$
\text { R-NH- } \mathrm{CH}_{2}-\mathrm{CH}_{2}-\mathrm{N}-\mathrm{CH}_{2} \mathrm{COOH}
$$

4

西ドイッの Goldschmidt 社で開発された殺菌剤で, テゴー51 とよばれる．食品工場などにおける有害微生物 の洗浄除去と殺菌に適している．家畜の飼料に用いる各 種の器材, 家畜の衛生, 微生物による飼料の変質防止な ぞに勃果があるので，家畜の伝染病の予防にすぐれた成 績を示している.

3) グアニジン誘導体

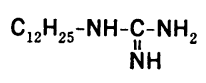

5

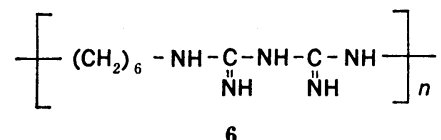

6

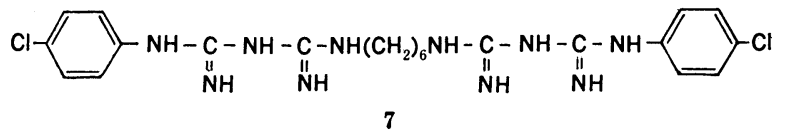


バイオチェック 60 (5) はアメリカのメルク社で開発 された繊維製品, 紙, パルプ用の殺菌剤で, 繊維に対し て親和性をもっている。広範囲の微生物を抑制すること ができ，毒性が低く，刺激性もないので，FDA から衣 料品や乳児用品の衛生処理剤として認可されている.

バントシル $1 \mathrm{~B}$ （6）はカチオン性の水溶性殺菌剤で, 食品工場, 製薬工場, 病院内の壁面, 天井, 作業台, 床 面の殺菌剤として使用できる.

ヒビテン（7）は一般にクロルヘキシジンとよばれ， 外科手術の分野で手指, 器具, 手術前の皮膚や患部の消 毒に使われ，また，化粧品や公衆衛生用として広く用い られている.

4） $\alpha, \beta$-不飽和カルボニル化合物

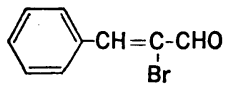

8

筆者らの開発した繊維用消毒剤で， $\mathrm{BCA}$ とよばれて いる. 徐々に気化して密閉容器内の細菌やカビの増殖を 抑制するユニークな性質がある. $\mathrm{BCA}$ をシリカゲルに 吸着させたものは, カラーフィルムの防徽剤として使用 されている。

5)フェノール類

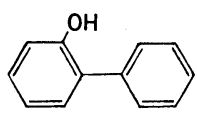

9

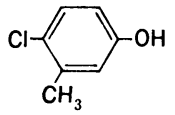

10<smiles>Cc1cc(O)cc(C)c1Cl</smiles>

11<smiles>Oc1c(Cl)c(Cl)c(Cl)c(Cl)c1Cl</smiles>

12<smiles>Oc1cccc2cccnc12</smiles>

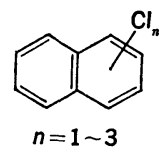

18<smiles>N#Cc1c(Cl)c(Cl)c(Cl)c(C#N)c1Cl</smiles>

19

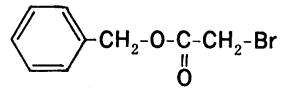

16

15 消毒剤として用いられる。

b） 反応性臭素化合物

ブロモ酰酸ベンジル（16）は水系塗料の防腐剂として 用いられ，バクトール $\mathrm{P}$, メルバック 35 , マスガー ドM201 などの市販品がある，2２-ジブロモ-2'-クロロ アセトフェノン（17）はスライムコントロール剂であ る.

c）不活性塩素化合物<smiles>CO[As](C)(=O)c1c(Cl)c(Cl)nc(Cl)c1Cl</smiles>

20 
クロロナフタレン類（18）は油溶性木材防腐郕として 用いられる．テトラクロロイソフタロニトリル（19）は 水系塗料の防腐郕で, 商品名にはノプコサイド $\mathrm{N}-96$ お よび N-54-D がある.4-メチルスルホニルテトラクロ ロピリジン $(20)$ はダウイシル S-13 として知られ，エ マルジョン塗料, 溶剤型塗料のほか, 接着剤, 目地七メ ソト，石膏ボードなどに添加される.

7）チオシアノ系化合物

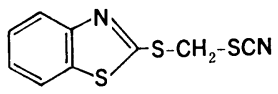

21

2-(チオシアノメチルチオ) ベンゾチアゾール (21) は 塗料および皮革用の防菌防徴剤であり，ブサン 72 の商 品名で市販されている.

8） ジチオカルハミミン酸系化合物<smiles>CNC(=S)N(C)C</smiles>

22<smiles>NS(=O)(=O)c1nc2ccccc2s1</smiles>

24<smiles>CN(C)C(=S)SSC(=S)N(C)C</smiles>

23<smiles>CN1CSC(=S)N(C)C1</smiles>

25

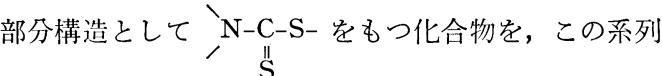
に分類した．24もナトリウム塩でなければ，この部分構 造をとる. ジメチルジチオカルバミン酸ナトリウム $(\mathbf{2 2})$ はスライム防除郕として用いられ，商品名にはミクロサ イド 100 がある. ビス（ジメチルジチオカルバモイル） ジスルフィド（23）はテトラメチルチウラムジスルフィ ド (TMTD) ともよばれ，水系塗料の不揮発分に対し， 4 6\% 添加すると塗膜の防カビに効果がある．2-メル カプトベンゾチアゾールナトリウム（24）は水系組成物 に用いられ，バンサイド 51 という市販品がある. 3,5ジメチルテトラヒドロ-1，3，5，2H-チアジアジン-2-チ オン（25）は主としてスライム防除に用いられ，商品名 にメタゾール D3T がある.
9）アミド系化合物

a) アニリド系化合物

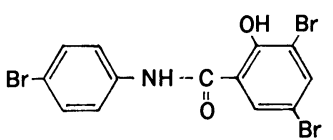

26

b）尿素系化合物<smiles>O=C(NC(=O)Nc1ccc(Cl)c(Cl)c1)Nc1ccc(Cl)cc1</smiles>

27<smiles>O=C(Nc1ccc(Cl)cc1)Nc1ccc(Cl)c(C(F)(F)F)c1</smiles>

28

3,5-ジブロモサリチル-4-ブロモアニリド $(\mathbf{2 6}), N$ (3,4-ジクロロフェニル)-N'-(4-クロロフェニル) 尿素 (27)，N-(3-トリフルオロメチルー4-クロロフェニル)-

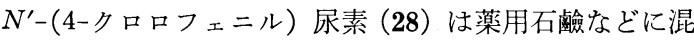
入され，皮膚の殺菌消毒に用いられる. 28 にはイルガ サン $\mathrm{CF}_{3}$ の商品名がある.

c）環状了ミド系化合物<smiles></smiles>

29<smiles>O=c1[nH]sc2ccccc12</smiles>

31<smiles>O=c1ccsn1[PbH]</smiles>

30

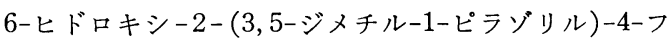
ェニルピリミジン（29, KN 747） は真菌およびグラム 陽性菌，とくに水虫菌および黄色ブドウ球菌に対し非常 
に強い抗菌力を示し，またナイロンに強く吸着するう え，柔軟化作用もあることが，筆者らにより見いださ れ; 靴下の衛生加工に用いられている。2-オクチルイン チアゾリン-3-オン $(30)$ は SKANE M-8 なる市販品 があり，亜鉛華と併用してェマルジョンペイントに用い られる１，2-ベンゾイソチアゾリン-3-オン（31）はエマ ルジョン塗料の防腐に用いられ，市販品にはプロキセル CRL がある.

10） ヨードプロパルギル系化合物

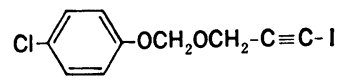

32

4-クロロフェノキシメチル-3-ヨード-2-プロピニルエ ーテル（32）はスライム防除郕であり, 商品名にはデニ サイド NS 100 がある.

11） Nーハロアルキルチオ系化合物<smiles>CN(C)S(=O)(=O)N(SC(F)(Cl)Cl)c1ccccc1</smiles>

33<smiles>O=C1C2CC=CCC2C(=O)N1SC(Cl)(Cl)Cl</smiles>

35

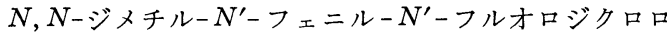
メチルチオスルフォミド（33）はプレベントール A4 と よばれ，不活性成分として安定剤など 10１2\%を含む 淡灰白色粉末として市販されている，広範囲の細菌およ びカビの発育を低濃度で阻止し，毒性もきわめて低い。 食品工場，化粧品工場の塗装に用いられ，化粧品，日用 品(マットレス, カーペット, 足ふき, 衣料品), エマル ジョン塗料にもよい成績を示している． $N$-(フルオロジ クロロメチルチオ)ーフタルイミド (34) はプレベントー ル A3 という商品名でドイッの Bayer 社より販売され ている. プラスチック用の防菌防徽剤であり, 塩化ビニ ルのシートやレザーを作るときの熱処理でも，薬郕が分 解しない点が利用上のメリットになっている，N-トリ
クロロメチルチオテトラヒドロフタルイミド（35）はキ ヤプタンという名称で知られ, 塗料, 皮革, プラスチッ クに用いられる。

12） ベンズイミダゾール系化合物

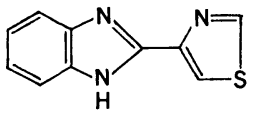

36

2-(4-チアゾリル) ベンズイミダゾール（36）はサイア ベンダゾール，TBZ などとよばれ，アメリカのメルク 社からメタゾール TK-100 という商品名で販売されて いる. 水にも有機溶剤にもきわめて溶けにくいが，酸や アルカリで分解することなく，耐熱性は $300^{\circ} \mathrm{C}$ まであ る.毒性に関するデータは 10 年以上にわたる実施例が あって, 現在市販されている薬剤では，もっとも安全性 が高い. 塗料, 水系組成物, 皮革, プラスチック，纎維 などに広範囲に用いられている。

13）有機金属化合物

a) 有機スズ化合物

$$
\left(\mathrm{C}_{4} \mathrm{H}_{9}\right)_{3} \mathrm{SnO}
$$

37
$\left(\mathrm{C}_{6} \mathrm{H}_{5}\right)_{3} \mathrm{SnOH}$

38 トリーnーブチルスズオキシド (37)，トリフェニルスズ ヒドロキシド（38）は木材の腐朽を阻止し，酎候性が大 きい. ペンタクロロフェノール（12）と同様に，褐色腐 朽菌には効力が大きいが，白色腐朽菌には効力が小さ W.

b）有機ヒ素化合物

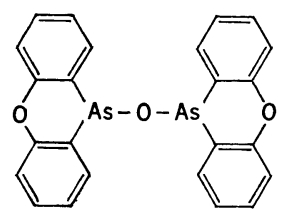

39

Vinyzene（39）はポリ塩化ビニル，ポリ酢酸ビニル， ポリウレタンに相溶性であり, 熱安定性と持続性がきわ めて優れている．活性原体とのものは市販されていない が，SB-1（ポリマー中 5\% 配合体）として販壳されて いる. 
14） の 他<smiles></smiles>

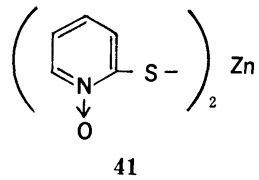

2-ピリジンチオールナトリウムー1-オキシド（40)，2ピリジンチオール亜鉛-1-オキシド (41) は切削油, ラテ ックス, 冷却用循環水などの防菌に効化がある.

\section{代表的防菌防徽剤の活性}

つぎに代表的な薬剤の発育阻止濃度を表 1 に示す.デ
一タは同一研究者によるものが，薬剤間の活性の比較に 信頼性があるので, 井上真由美氏の測定結果のみを示 す。なお，表の末尾に使用分野を丸印で示した。

\section{おわりに}

水銀剤が全盛であった 20 年ほど前に，筆者が BCA の実用化に取り組えだ時代にくらべると, 防菌防徽に関 する意識は隔世の感がある. 防菌防徽学会の設立を契機 として, 微生物災害が幅広い業界分野において問題にな っており，その解決方法に悩えでいることが明らかにな ってきた. とくに，微生物を知っている技術者のいない 工業分野では，その対策に手も足もでない状況にあった といえる. 防菌防徽学会の短期間における成長は，この ような潜在的ニーズに答えだため思われる. その点

表 1 代表的薬剤の抗菌抗カビ活性

\begin{tabular}{|c|c|c|c|c|c|c|c|c|c|c|c|c|c|c|c|c|}
\hline \multirow{3}{*}{ 菌 名 } & \multicolumn{16}{|c|}{ 阻 止 濃 度 (ppm) } \\
\hline & \multicolumn{16}{|c|}{ 化 合 物 番 号 } \\
\hline & 4 & 5 & 6 & 7 & 8 & 9 & 11 & 16 & 19 & 20 & 31 & 33 & 34 & 36 & 39 & $\mathbf{4 0}$ \\
\hline \multicolumn{17}{|l|}{ 真 菌 } \\
\hline Aspergillus niger & 300 & 100 & 一 & 50 & 40 & 15 & 100 & 10 & 600 & 10 & 300 & 6 & 70 & 10 & 5 & 10 \\
\hline A. flavus & 500 & 110 & - & 60 & 40 & 10 & - & - & 500 & 15 & - & 5 & - & 15 & 8 & - \\
\hline A. oryzae & 600 & - & 一 & - & - & 10 & - & - & - & - & - & 3 & - & 25 & 5 & - \\
\hline $\begin{array}{l}\text { Aureobasidium } \\
\text { pullulans }\end{array}$ & 150 & - & - & - & 15 & 10 & - & 一 & 300 & 10 & - & 3 & - & 0.2 & 3 & - \\
\hline Chaetomium globosum & 200 & 40 & 一 & - & - & - & 100 & 一 & 300 & 15 & - & 10 & 一 & 5 & 一 & 10 \\
\hline Cladosporium resinae & 200 & 20 & - & 一 & 一 & - & 一 & 一 & 一 & 一 & 一 & 5 & 一 & 10 & 3 & - \\
\hline C. herbarum & 300 & 30 & 一 & 80 & 10 & 20 & 70 & 5 & 800 & 20 & 100 & 一 & 80 & 15 & 3 & 一 \\
\hline Fusarium moniliforme & - & - & - & 80 & 50 & 一 & 150 & 25 & 700 & 110 & 500 & 15 & 150 & - & 5 & 30 \\
\hline Penicillium citvinum & 200 & 50 & - & - & 5 & 15 & 80 & 10 & 600 & 20 & 150 & 6 & 40 & 15 & 3 & 20 \\
\hline Rhizopus nigricans & 300 & - & - & - & 10 & 30 & - & 30 & - & 15 & 400 & 10 & - & 30 & 10 & 一 \\
\hline Saccharomyces cerevisiae & 一 & 40 & 50 & - & - & 一 & 400 & 5 & - & - & 200 & 50 & - & - & - & 一 \\
\hline Trichoderma $\mathrm{T}-1$ & 一 & 一 & 一 & - & 30 & - & 180 & 35 & 1100 & 50 & - & 40 & 40 & 10 & - & 30 \\
\hline \multicolumn{17}{|l|}{ グラム陽性菌 } \\
\hline Bacillus subtilis & 1200 & 60 & 70 & - & 10 & 60 & 200 & - & 25 & 150 & 100 & 30 & 6 & - & 3 & 20 \\
\hline Staphylococcus aureus & 800 & 50 & 30 & 5 & - & 50 & - & 10 & 15 & 10 & 30 & 20 & - & - & 15 & - \\
\hline \multicolumn{17}{|l|}{ グラム陰性菌 } \\
\hline Escherichia coli & 1000 & 40 & 40 & 20 & 10 & 80 & 250 & 15 & 一 & 200 & 30 & 15 & 10 & - & 3 & 20 \\
\hline Pseudomonas aeruginosa & 1000 & 80 & 80 & 30 & 70 & 170 & 1200 & 5 & - & 900 & 200 & 20 & 100 & - & 30 & 40 \\
\hline Proteus vulgaris & 1000 & 25 & - & 25 & - & 一 & 500 & - & 300 & 150 & 90 & 30 & - & - & 10 & - \\
\hline \multicolumn{17}{|l|}{ 応用分野 } \\
\hline 塗料 & & & & & & & & & & $\mathrm{O}$ & 0 & $\bigcirc$ & & $\bigcirc$ & & \\
\hline 水系組成物 & & & & & & & & $\bigcirc$ & $\bigcirc$ & & & & & $\bigcirc$ & & $\bigcirc$ \\
\hline 皮革 & & & & & & & $\bigcirc$ & & & & & & & $\mathrm{O}$ & & \\
\hline プラスチック & & & & & & & & & & & & & 0 & 0 & 0 & \\
\hline 繊維 & & 0 & & & 0 & & & & & & & & & 0 & & \\
\hline 殺菌消毒 & $\bigcirc$ & & $\bigcirc$ & $\bigcirc$ & & & & & & & & & & & & \\
\hline
\end{tabular}


で,アルミニウムの微生物による腐食を世に紹介し, さ らに防菌防徽に関する指導に活躍された井上真由美氏の パイオニヤ的存在も忘れることはできない.ともかく， 防菌防徽学会誌や井上真由美氏の著書を通じて, 微生物 災害の実体を知るにつけ，防菌防徽剤に関しては，さら に理想的な性質をもった薬羭の出現が望をれるわけであ るが, 安全性などの問題で開発に要する経費は著しく大 きくなってきて抢り, 新しい薬郕の開発は巨大企業以外 では不可能に近い状態になっている. 農業用殺菌郕の場 合には直接的な抗菌作用によって病害防除作用を発揮す るものとは限らないが，工業用防菌防徽剂を望む側から いえば, 直接的抗菌活性を示す新しい農業用殺菌剂が現 われて，それがどこかの工業分野で使用できる性質を備 えてくれたらよいと思う。しかし，これはあまりにも虫 のよい注文である. やはり, 農薬メーカーが, 農薬開発 に伴って合成される膨大な数の化合物を工業用防菌防徵
凨という観点から眺めて，その開発に結びつけてくれる ことが望ましい. 大型農薬とは比較にはならないかもし れないが，多くの工業分野で使用できるものであれば， その使用量はばかにならないのではないかと思う。ぜひ とも, このような視点から農薬開発を進めてほしいもの である。

\section{引用文 献}

1) 井上真由美: 微生物災害と防止技術, 工学図書株 式会社, 1977

2）西村民男：微生物学基礎講座テキスト，日本防菌 防徽学会, 1978

3）西村民男 - 渡辺昭一郎 - 内堀 毅：新界面活性剂 の機能作用の解明とその応用製品の開発総合技術資 料集, 経営開発センター出版部, p. 269, 1980

4) 防菌防徽誌 